\title{
External Ophthalmomyiasis Caused by Oestrus Ovis
}

\section{Oestrus Ovis'in Neden Olduğu Eksternal Oftalmomiyazis}

Zeynep Dadaci ${ }^{1}$

Beyza Saracligil²,

Salih Macin ${ }^{3}$

${ }^{1}$ Medicana Konya Hospital, Ophthalmology Department, Konya, Turkey

${ }^{2}$ Medicana Konya Hospital, Department of

Medical Biochemistry, Konya, Turkey

${ }^{3}$ Selcuk University Faculty of Medicine,

Department of Medical Microbiology, Konya, Turkey

Geliş Tarihi/Received: 13 July 2018

Kabul Tarihi/Accepted: 12 September 2018

Address correspondence to: Zeynep Dadaci, Medicana Konya Hospital, Ophthalmology Department, Konya, Turkey

e-mail: zdadaci@hotmail.com

ORCID

Zeynep Dadaci

https://orcid.org/0000-0002-0246-4066

Beyza Saracligil

https://orcid.org/0000-0003-3147-3719

Salih Macin

https://orcid.org/0000-0002-1871-3629

\section{Öz}

External ophthalmomyiasis is infestation of ocular surface with fly larvae. In our report, we described a 47-year-old man who presented with complaints of foreign body sensation, itching and redness in the right eye. Slit-lamp biomicroscopy revealed tiny larvae crawling on the conjunctival surface. A total of four larvae were removed under topical anesthesia and sent to laboratory where they were identified as first stage larvae of oestrus ovis. Topical antibiotic-steroid combination drop was prescribed. The patient had no complaints in the follow-up examinations. External ophthalmomyiasis should be remembered in the differential diagnosis of red eye as myiasis may also occur in healthy people living in city centers.

Anahtar Kelimeler: External ophthalmomyiasis, fly larvae, oestrus ovis

\section{Abstract}

Eksternal oftalmomiyazis oküler yüzeyin sinek larvaları tarafından infestasyonudur. Bu yazıda sağ gözünde yabancı cisim hissi, kaşıntı ve kızarıklık şikayeti ile başvuran 47 yaşında bir olguyu tarif ettik. Yarıkı lamba biyomikroskopisinde konjonktival yüzeyde hareket eden küçük larvalar izlendi. Toplamda dört larva opikal anestezi altında cıkarılarak laboratuvara gönderildi ve oestrus ovis birinci evre larvaları olarak tanımlandı. Topikal antibiyotik-steroid kombinasyonu damla reçete edildi. Hastanın takip muayenelerinde herhangi bir şikayeti olmadı. Miyazisin şehir merkezlerinde yaşayan sağlıklı bireylerde de gelişebileceği göz önünde tutularak kırmızı gözün ayırıcı tanısında eksternal oftalmomiyazis hatırlanmalıdır.

Key words: Eksternal oftalmomiyazis, sinek larvası, oestrus ovis

\section{INTRODUCTION}

Myiasis is infestation of living human or other vertebrate animals with fly larvae which are insects of the order Diptera. Larvae can infest various tissues and regions of the body. Traumatic (myiasis of wounds), ocular, nasal, oral, aural, enteric, urogenital and rectal myiasis are reported in humans (1). Infestation of the eye by the larvae of dipterous flies is called ophthalmomyiasis (2). Three types of ophthalmomyiasis are defined; external when larvae are deposited on the ocular surface or eyelid, internal when larvae invade the globe, and orbital where the orbit is involved.3 In external ophthalmomyiasis, which is the most frequently encountered type, patients usually present with a complaint of foreign body sensation and may have conjunctival hyperemia, chemosis, eyelid edema and erythema, conjunctival hemorrhages, punctate keratitis, and keratouveitis (4).

Several fly species are reported to cause ophthalmomyiasis but the most common parasite encountered in external ophthalmomyiasis is oestrus ovis (2). Also called sheep nasal bot fly, this parasite is common in the nasal and paranasal cavities of 
goats and sheep. Therefore, it is more commonly encountered in tropical regions or sheep-farming areas in the Mediterranean countries, but several cases are also reported in urban regions (2).

External ophthalmomyiasis is a rare phenomenon, but it is believed that the exact frequency of the disease is much higher as most cases are not reported (5). Herein, we report a case of external ophthalmomyiasis caused by oestrus ovis, who was successfully treated with topical antibiotic-steroid combination after mechanical removal of the larvae.

\section{CASE}

A 47-year-old man presented to our clinic with complaints of itching, redness and moving foreign body sensation which started after the strike of a fly while he was working in the garden. The best corrected distance visual acuity was 20/20 in both eyes. The eyelid was edematous and conjunctiva was hyperemic on the right side. Slit-lamp microscopy revealed three tiny larvae about $1 \mathrm{~mm}$ length crawling on the conjunctival surface. The larvae were highly motile and tend to move away from the bright light of the biomicroscope. The cornea was clear, and no cellular reaction was observed in the anterior chamber. Three larvae were removed by cotton tipped applicator after application of topical anesthesia and sent to laboratory for identification. After removal of the larvae, the conjunctival surface and fornices were examined again for any remaining larvae. As no further larvae were found, topical antibiotic-steroid combination (Dexamethasone $0.1 \%$ + Netilmicin $0.3 \%$, $4 \times 1$ ) was prescribed and the patient is instructed

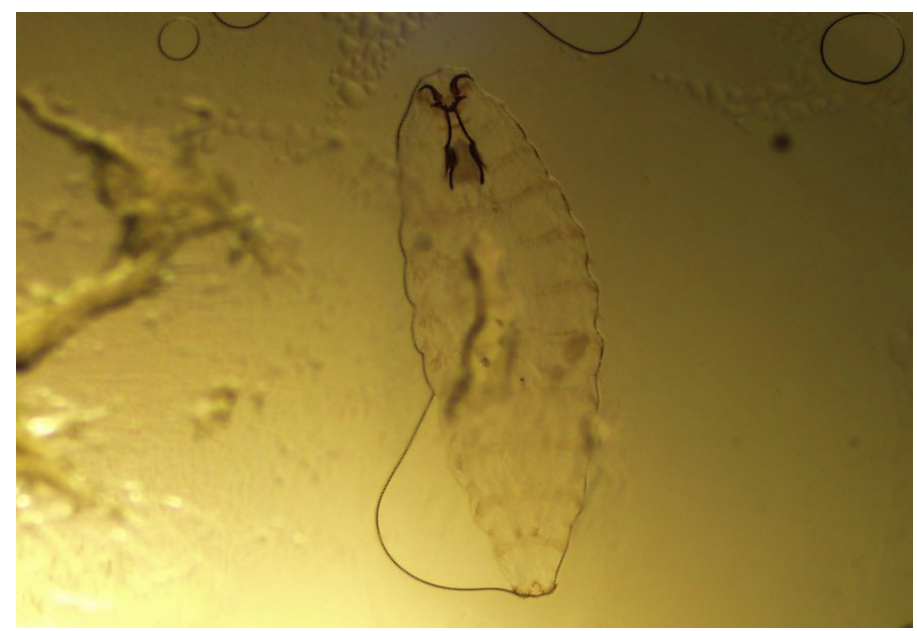

Figure 1. The first stage of Oestrus ovis larva

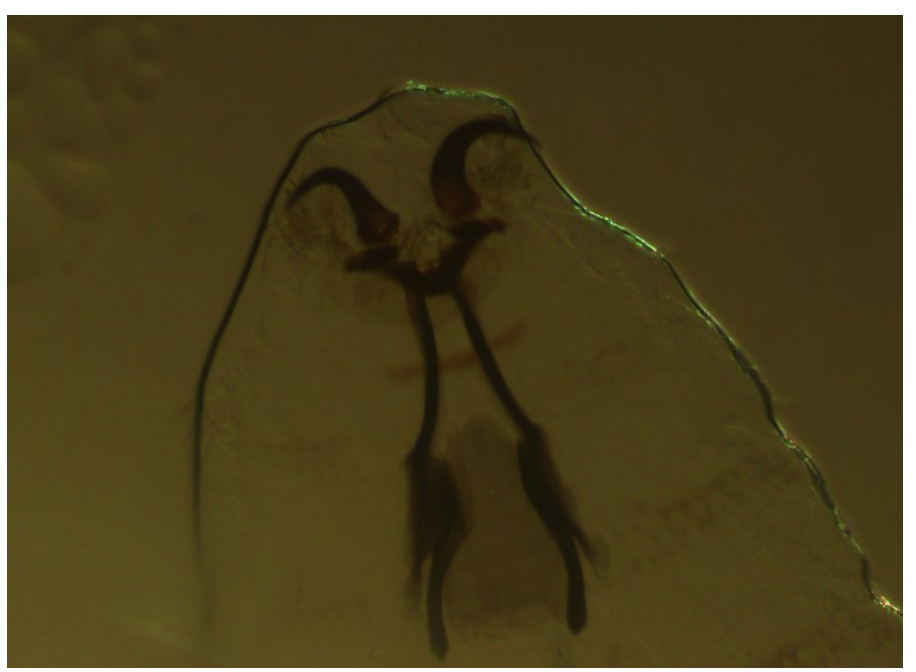

Figure 2. Internal structures of the Oestrus ovis larva seen in high magnification

to return upon recurrence of complaints, and called for follow-up. The patient returned two hours later with the complaints of persistence of foreign body sensation and itching. We removed one further larva and followed the patient for recurrence of symptoms. No further larvae was observed, and the patient was free of complaints in the follow-up examinations.

The light-microscopic examination showed that the larvae were flat dorso-ventrally, had double-row of spin on the ventral side of the segments and a pair of black colored hooks on the anterior part, identified as first stage oestrus ovis larvae (Figures 1 and 2).

\section{DISCUSSION}

Several species of flies belonging the order diptera have been identified to cause myiasis in vertebrate animals and humans. Of these, Oestrus ovis (sheep nasal bot fly) is one of the most common agents reported to cause human myiasis (2). Sheep and goats are the normal hosts for the Oestrus ovis larvae. Adult female flies deposits their larvae near the nostrils of these animals. Larvae enter the nasal cavity or sinuses of the sheep where they mature in three stages, then leave the animals and enter into the pupal stage to complete their development as mature flies 6 . Humans are accidental hosts and infestations of various regions of the body, skin and ocular surface being the most common, have been described (1). Usually first stage larvae are reported in myiasis of humans (7). We also observed first stage larvae in our case. 
Several predisposing factors are described to facilitate human myiasis such as poor hygiene and low socioeconomic status; wounds that are either traumatic or surgically induced; advanced age; chronic infections; debilitating diseases and close contact with farm animals or living near sheep-farming areas $(1,7)$. But myiasis, especially external ophthalmomyiasis, is also commonly reported in healthy subjects without any known risk factors living in urban areas. Özyol et al. $(5,7)$ reported three consecutive cases of external ophthalmomyiasis diagnosed in a week, none with a history of exposure to farm animals. The authors pointed out that most human ophthalmomyiasis cases reported in Turkey are those living in urban areas without any contact history with animals, most likely due to unreported cases in rural areas. They argued that ophthalmomyiasis may be much more frequent than that reported as it can be treated empirically. 5 The prevalence of human myiasis can be more exactly figured out by cross-sectional studies, but most reports in the literature are case reports and case series (2). In one previous study conducted in the Etnean area (Sicily) during which 112 shepherds were interviewed, it was found out that 90 of them $(80.3 \%)$ had contracted Oestrus ovis myiasis at least once in their lives. Only 7 out of 90 shepherds went to see a doctor and most preferred traditional treatment methods (8).

The most common causative agent in external ophthalmomyiasis is Oestrus ovis but many other fly species were also reported as a cause (2). As Oestrus ovis larvae do not release proteolytic enzymes 6 most, if not all, cases of ophthalmomyiasis reported to be caused by Oestrus ovis are external. We could find only one report ophthalmomyiasis interna case in the literature caused by Oestrus ovis (9). However, there are some species of flies capable of invading the ocular structures (2). Therefore, exact taxonomic identification of these larvae may be helpful in estimation of the risk of possible complications.

Although mechanical extraction is usually sufficient for removal of the larvae in external ophthalmomyiasis, it must be remembered that there may be residual larvae because they are very mobile and tend to hide as they dislike bright light. Irrigation of ocular surface is usually insufficient because larvae can attach the mucosa firmly with their hooks (7). Prior application of topical cyclopentolate or topical ivermectin is reported to immobilize or kill larvae and facilitate their mechanical removal $(10,11)$. Anti-inflammatory drugs are prescribed to control host reaction and antibiotics against secondary infections.

In conclusion, although external ophthalmomyiasis is not a common disease, it is important to remember this condition in the differential diagnosis of patients with conjunctivitis even in the absence of a history of visiting sheep farming areas as myiasis may also occur in healthy people living in city centers. Careful follow-up and taxonomic identification is important to detect remaining larvae and to exclude the possibility of presence of other types of larvae that are capable of invading deep ocular structures.

Conflict of interest: Authors declare that there is no conflict of interest between the authors of the article.

Financial conflict of interest: Authors declare that they did not receive any financial support in this study.

Address correspondence to: Zeynep Dadacı, Havzan Mah. Yeni Elektrik Santral Cad. Altınbaşak Konakları 4C/4 Konya / Türkiye

Tel: +90 5337269070 e-mail: zdadaci@hotmail.com

\section{REFERENCES}

1. Francesconi F, Lupi O. Myiasis. Clin Microbiol Rev 2012;25(1):79-105.

2. Singh A, Singh Z. Incidence of myiasis among humans-a review. Parasitol Res 2015;114(9):3183-99.

3. Bosniak SL, Schiller JD. Ophthalmomyiasis in an eyelid reconstruction. Am J Ophthalmol 1990;109(1):101-2.

4. Jenzeri S, Ammari W, Attia S, et al. External ophthalmomyiasis manifesting with keratouveitis. Int Ophthalmol2009;29(6):5335.

5. Özyol P, Özyol E, Sankur F. External ophthalmomyiasis: A case series and review of ophthalmomyiasis in Turkey. Int Ophthalmol. 2016;36(6):887-891.

6. Cepeda-Palacios R, Scholl PJ. Gonotrophic development in Oestrus ovis (Diptera: Oestridae). J Med Entomol 1999;36(4):435-40.

7. Dunbar J, Cooper B, Hodgetts T, et al. An outbreak of human external ophthalmomyiasis due to oestrus ovis in southern afghanistan. Clin Infect Dis 2008;46(11):e124-6.

8. Pampiglione S, Giannetto S, Virga A. Persistence of human myiasis by oestrus ovis L. (Diptera: Oestridae) among shepherds of the etnean area (Sicily) for over 150 years. Parassitologia 1997;39(4):415-8.

9. Rakusin W. Ocular myiasis interna caused by the sheep nasal bot fly (Oestrus ovis L.). South Afr Med J Suid-Afr Tydskr Vir Geneeskd 1970;44(40):1155-7.

10. Sundu C, Dinç E, Kurtuluş UC, et al. Ophthalmomyiasis externa: A report of three cases. Turk $\mathrm{J}$ Ophthalmol 2015;45(5):220-2.

11. Denion E, Dalens $\mathrm{P}-\mathrm{H}$, Couppié $\mathrm{P}$, et al. External ophthalmomyiasis caused by dermatobia hominis. A retrospective study of nine cases and a review of the literature. Acta Ophthalmol Scand 2004;82(5):576-84. 